325.254:355.45-042.3(497.7:497)

\title{
The Influence of Mixed Migrations on the Safety of Republic of Macedonia and the Balkans
}

\author{
ZLATKO NIKOLOSKI, Ph.D \\ Ministry of Interior of the Republic of Macedonia - National Coordinative Center of \\ Border Management \\ E-mail: zlatko.nikoloski@yahoo.com \\ MARJAN MLADENOVSKI Ph.D \\ Euro College, Faculty of business administration - Kumanovo \\ E-mail: mladenovskimarjan@gmail.com
}

\begin{abstract}
The dynamics of mixed migrations in our region which, thanks to its geographic location and its connection with the European countries is becoming ever more attractive for transit, but also a destination of a large number of migrants and Third World refugees is growing.

All researches and available data indicate that the Balkans is nowadays both the location of origin and a destination of human trafficking, the main route of the Near East refugee crisis, migrant and drug trafficking, as well as a transit point for illegal migration of many African refugees. This paper analyzes the capacities of the Balkans for a regional cooperation in the field of migrations and asylum, because this issue cannot be treated separately as a problem or an advantage of one country, and whether the regional mechanisms and the cooperation with the EU in confronting illegal migration and overboard crime, the legislative and the regional initiative which develops a comprehensive approach of migration management and protection of the migrants, as well as the asylum issue, the systemic setup of the responsible security services in the countries of the region are efficiently organized to manage the migration processes as well as the ever-intensifying security threats.
\end{abstract}

Keywords: mixed migrations, region, institutions, capacities, cooperation 


\section{Introduction}

The Balkans, located between the East and the West, are becoming an ever more interesting geographic, geopolitical, and security-related subject of analysis of many EU, Balkanic and world politicians, some of the subjects including the location through which the main route of migrants towards Europe was and is still passing for the citizens of the countries from the Near East, Afghanistan, Pakistan, but also from some African countries.

A large number of people decide to migrate to the EU countries from the Near East and from North Africa due to economic reasons, but also under the pressure of the military conflicts. Migration is becoming an issue that needs global approach and coordinated solutions. Countries are lately intensively discussing about the migration issues on bilateral level, but the need to address it on a regional and, since recently, on a global level is imposing.

Migrations are mainly directed towards Germany. The migrants' route is used by many criminal bands for human trafficking, migrant smuggling and drug dealing, but also for support to the movement of terrorists from the East who, as a consequence of the change in the dynamism of the military actions, try to escape from the locations where they were hired and involved in murders of military personnel but also of civilians who use this route to advance towards the EU.

The analysis of such dynamism of migrations and the course of events leads to the obvious conclusion that the migrations are mainly of a mixed character, that they are used for diverse purposes but represent a serious menace to the peace and security in the Balkan region, as well as in the Republic of Macedonia, which is located on the most geographically and politically frequent "crossroads" of these events.

Such circumstances inevitably raise the question of cooperation in the field of security, migrations and asylum not only on the regional, but also on a wider, European level, as well as of the cooperation with NATO as the most modern form of organization in view of world security protection, because it is not possible to treat this issue as a separate problem or benefit of a respective country.

As for the migrations that have, for already quite a long period of time, been manifested as mixed migrations: refugees, asylum seekers, illegal migrations, migrant smuggling, human trafficking etc., it must be noted that the number of illegal migrants 


\section{Seccurity}

and asylum seekers is lately continually increasing, and that the countries of their origin nave changed.

Republic of Macedonia has put great efforts to manage the mixed migrations in recent years, especially the migrant inflow from Greece, which refused to cooperate with Macedonia for a considerable period of time; this resulted in a collapse on the north Greek border, passing the burden of finding the solution onto the Republic of Macedonia, which was, at first, left to protect its south border alone, thus protecting EU, i.-e the "external EU border" from illegal immigrants, although it was from an EU Member-state, that is, from Greece, that the biggest problems for Macedonia was coming from. Greece failed to manage its southern islands and water border in compliance with the European regulations on the protection of external borders as pursuant to the Dublin Convention ${ }^{68}$, and to other regulations by which Greece is obligated to take security actions in view of the protection of the EU external borders.

The decision of Germany to suspend the Dublin Convention, according to which the refugees were obligated to seek asylum in the first country they set foot on, caused exaltation among the migrants, especially because the message of the German authorities to all migrants emphasized that Germany would temporarily shelter all refugees, which incited them to choose Germany, and not any other Western European country as their final destination.

But, a wider analysis of this situation immediately led to the conclusion that EU itself failed the plan of protection of its own borders, but also on the plan of respecting its own regulations that the huge EU bureaucracy had spent a lot of money to enact; this especially refers to the FRONTEX mission as a specialized EU organization for protection of the EU external borders.

Hence the serious challenge that incurred not only for the Republic of Macedonia, but also for the other Balkan countries that wanted to protect their borders against illegal intrusion and the potential threats to the security of each respective state, on the one hand, and, on the other hand, the need to act in compliance with the

${ }^{68}$ Dublin Convention is a treaty among EU states (adopted in 1990, came into force in 1997) which determines the EU Member-state responsible to review an asulum application submitted in one of the convention signatories. The said convention prevents the search of the same applicants by several EU Member states simultaneously, also providing the re-direction of the asylum seeker from one country to another, simply because no one wants to take the responsibility of their case. 


\section{Seccurity}

international laws regarding the human rights protection and the refugee rights, that is, to adjust their policies and practice to the newly arisen real situation.

The main direction of the research and the analyses in this paper are the description and the conclusion regarding certain situations and tendencies of creation of valid estimations about the influence of mixed migrations on the security of the country, but also identification and the confrontation with the counter-indications so as to identify a safe solution of management of the said mixed migration processes.

\section{Influence of the mixed migrations on the security of the Balkans and of Republic of Macedonia}

The world and especially the EU witness examples of countries that besides their coherent migration policy, supported by regulations, frequently expe

rience serious difficulties regarding security and migration management, especially in the recent years when the migrations are of mixed character. The problem becomes even more complicated if the said management comes untimely, that is, when measures and activities to prevent the unwanted effects and their influence on the country's security are not taken when necessary ${ }^{69}$.

Migration, especially the illegal mixed migration, obviously requires timely and permanent inter-ministry cooperation and coordination, including the most important instances on this level, as are the Ministry of Interior, Defence Minsitry of the Republic of Macedonia, the Crisis Management Center, the Ministry of Labour and Social Policy, Ministry of Health, as well as the other ministries and responsible sectors involving all the capacities and very often some regional cooperation as well.

Macedonia has seriously felt the pressure and the security risk of mixed migrations in the last three years, especially with the massive migration wave of people from the Near and Far East in 2015, when the only positive signal was the fact that Macedonia was recognized only as a transit destination towards EU.

\footnotetext{
${ }^{69}$ migration management is a notion sovering a large number of Government functions and a nation-wide system of organized and humane management of cross-border migrations, especially the entry and presence of foreigners within the borders of a country and protection of refugees and other people in need of protection.
} 
Nevertheless, Macedonia suffered serious implications regarding the management of such challenges. The experience of the 1999 Kosovo crisis, all security services, the inclusion of all capacities and the army of Macedonia, the NGO sector and the International organizations such as IOM, UNHCR, the Macedonian Red Cross, contributed to safe crisis management and provided protection to migrants as a modern state, according to the international conventions and directives. ${ }^{70}$

Mixed migrations undoubtedly complicate the support to the real refugees and asylum seekers who need protection in the first safe country that they reach, but considering that the first safe country besides Turkey is Greece, the usual European practice regarding immigration and refugee policy ${ }^{71}$ was put in question, and asylum seekers were allowed to "choose the country that they consider as safe" which, for the largest number of migrants, especially for those coming from the East, was Germany; on the other hand the African migrants emphasized France and England as safe countries.

Such "new" immigration policy of the EU, and especially of Germany, towards the refugees, made it possible for the majority of the to head to Germany, followed on that route by migrant smugglers, human traffickers, threats, attacks from criminals etc.

The large number of migrants in the massive mixed migrations brought other types of security menace but also financial implications as: illegal entry into Macedonia $^{72}$, insufficient accommodation capacities for the asylum seekers, the

${ }^{70}$ The change in the structure of illegal migrants incited certain challenges that were not prominent in the past years (lack of translators of Arabic language and of the dialects spoken by the illegal migrants, lack of valid readmission contracts with the Asian and African countries, the increased number of people and of their stay in the Shelter Center, the significantly higher financial funds for their possible return to their country of origin, lack of programs for assisted voluntary return, risks to public health etc.

${ }^{71}$ refugee (recognized) is a person who, as a result of wellgrounded fear of prosecution for reasons such as race, religion, nationality, membership in certain social groups or political views, is outside their country of origin is unable or, as a result of the said fear, is not willing to submit to the protection of that country (Refugee Status Conventio, Art. 1aA (2), 1951, modified by the 1967 Protocol.

72 llegal entry is an act of frontier passage without adherence to the necessary requirements regarding legal entry into the receiving country (Article 39b), UN Protocol against Smuggling of 


\section{Seccurity}

increased number of individuals seeking asylum, accidents on their migration route, which, in the beginning, largely followed the railway through Macedonia, crimes committed by Macedonians but also by foreigners who established a "chain of cooperation" among perpetuators from several countries along the route as migrant smugglers, riots in the Shelter for Foreigners, due to the insufficient space and poor accommodation conditions etc. ${ }^{73}$

Such mixed migration movements resulted in three serious threats: wave of refugees, who are already in large numbers in te region and in Macedonia, the terrorism threat as well as the menacing advocates of the radical Islamic groups fighting there but originating from the Balkans and from Macedonia.

Also, following the security condition and the migration dynamism in Africa, the announcements received on the second migration wave, on which there are serious indications, but also insights of its approaching the EU, will result in security risks

Migrants by Land, Sea or Air, Amendment to the UN Convention Against Transnational Organized Crime, 2000).

73 Directive no 2002/90/EC of the Council of 28 November 2002 defining the aid of unauthorized entry, transiting and residence.

Foreigners who, for any reasons, can not be removed from the territory of the Republic of Macedonia, are accommodated in the Foreigners' Shelter of the Ministry of Interior. In case of any prolonged stay of the foreigner citizen in the Shelter Center, the Minsitry of Interior brings a decision on their temporary detention, against which the citizen is entitled to lodge a complaint to the Commission in charge at the Macedonian Government. The re asons for which the foreign citizen can be expelled from from the Republic of Macedonia correspond to Article 1 of the EC Directive 2001/40/EC of 28 May 2001 on common recognition of decisions on rejection of third country citizens.

Understanding that the efficient efforts against illegal migration inevitably impose the need to strengthen the punitive policy, the Law on Foreigners introduces the following acts of crime: "assisting a foreigner in illegal entry and tansit" - Article 147 and "assisting a foreigner in their illegal residence" - Article 148. The establishment of legal regulations regarding the mentioned acts 0 crime was pursuant the EC 2002/90/EC Directive which defines assistance to unallowed entry transit and residence and the Framework Decision no. 2002/90/EC of the Council, defining assistance of illegal entry, transit and residence, as well as the Framework Decision no. 2002/949/JNA of 28 November 2002 on the strengthening of the penal legislation framework in favour of preventing the allowance of illegal entry, transit and residence adapted toth e penal system of the Republic of Macedonia. 
different from the period of the arrival of refugees from the war-stricken Near East, following the central Mediteranian corridor leading towards Italy.

Thousands of migrants head to the Italian coast on a daily basis, coming mainly from Africa, mostly from Libya and Egypt, but there is also a possibility of another refugee wave fromTurkey towards the Balkans and Macedonia, following the known Maceodnian route, if the EU and Turkey fail to find a solution to their opposed interests, which are becoming ever more complicated.

All these threats are completed by the fact that the majority of refugees originate from countries stricken by ebola, malaria and measles and that the refugees enter the country without being subjected to any medical control or any supervision, thus creating a serious epidemiological risk, due to which the problem and the menace to the security of the citizens of Macedonia, the region and Europe really becomes serious.

The analysis of the statistical data presented by the International Center of Study of Radicalism, Brukings Institute, in the table below, shows the total number of individuals that have left to fight in Syria and Iraq, since the conflict started. The number includes casualties and people who retired from the conflict zone. The numbers are alarming, as there is almost no region wherefrom no people have left to fight. The number of such people from Western Europe $(5,480)$ is particularly worrying. Considering that many of them could not or must not use public transport to return to their homes, it can be concluded that they they have well used the migrant route towards the EU, which mainly led through the Balkans and Macedonia. 


\section{Seccurity}

Table no 1. Legion of foreign fighters in Islamic State. Total number of passengers who left to fight in Syria and Iraq since the bginning of the conflict.

\begin{tabular}{|c|c|}
\hline WESTERN EUROPE & $\begin{array}{l}\text { NUMBER OF PEOPLE LEFT TO FIGHT IN } \\
\text { SYRIA AND IRAQ }\end{array}$ \\
\hline France & 1.500 \\
\hline United Kingdom & 700 \\
\hline Germany & 680 \\
\hline Belgium & 650 \\
\hline Turkey & 600 \\
\hline Sweden & 300 \\
\hline The Netherlands & 250 \\
\hline Austria & 150 \\
\hline Denmark & 150 \\
\hline Norway & 140 \\
\hline Spain & 100 \\
\hline Italy & 90 \\
\hline Finland & 70 \\
\hline Ireland & 60 \\
\hline Switzerland & 40 \\
\hline TOTAL: & 5.480 \\
\hline \multicolumn{2}{|l|}{ NORTH AMERICA } \\
\hline USA & 130 \\
\hline Canada & 100 \\
\hline TOTAL: & 230 \\
\hline \multicolumn{2}{|l|}{ NEAR EAST } \\
\hline Saudi Arabia & 2.500 \\
\hline Jordan & 1.500 \\
\hline Lebanon & 900 \\
\hline Israel / Palestine & 120 \\
\hline Jemen & 110 \\
\hline Kuwait & 70 \\
\hline TOTAL: & 5.200 \\
\hline \multicolumn{2}{|l|}{ AFRICA } \\
\hline Tunisia & 3.000 \\
\hline Morocco & 1.500 \\
\hline Libya & 600 \\
\hline Egypt & 360 \\
\hline Algeria & 250 \\
\hline Sudan & 100 \\
\hline Somalia & 70 \\
\hline TOTAL: & 5.880 \\
\hline
\end{tabular}




\begin{tabular}{|c|c|}
\hline FORMER EAST BALKANS & \\
\hline Russia & 1.500 \\
\hline Uzbekistan & 500 \\
\hline Bosnia & 380 \\
\hline Turkmenistan & 360 \\
\hline Kazakhstan & 250 \\
\hline Kosovo & 220 \\
\hline Tajikistan & 190 \\
\hline Albania & 140 \\
\hline Kyrgyzstan & 100 \\
\hline Serbia & 100 \\
\hline Ukraine & 50 \\
\hline TOTAL: & 3.790 \\
\hline \multicolumn{2}{|l|}{ ASIA AND THE PACIFIC } \\
\hline Pakistan & 500 \\
\hline China & 300 \\
\hline Australia & 250 \\
\hline Indonesia & 60 \\
\hline Affhanistan & 50 \\
\hline TOTAL: & 1.160 \\
\hline
\end{tabular}

Source:International Center of Study of Radicalisation, Brookings institute, EU

\section{Irregular migration}

The last years of the $20^{\text {th }}$ century passed, and the new century began with a great dynamism on the military plan, military interventions, terrorist activities from diverse groups, but also massive geopolitical changes worldwide, causing disturbance of the people in North-West Africa, the Near East (Libya, Egypt) etc.

This incited millions opf people to leave their locations of residence in search of better life, especially after the wars in Afghanistan, Iraq, the Arabian spring and Syria. The migration of some of those people towards the EU countries was illegal.

The pressure onto the European region was increased by the African migrants mainly coming from North-West Africa (Niger, Nigeria, Mali, Sudan and Somalia from Eastern Africa), with the occurrence of the terrorist organizations like Boco Haram, but also as a result of the unfavourable economic situation, the famine and poverty. 


\section{Securiagues}

Unlike regular migration, the irregular one is a process of movement involving illegal methods of entry and residence of people seeking better life regardless of the means used to reach their desired destination, i.-e. country.

Irregular migration is a method that jeopardizes the immigration laws of the destination country. ${ }^{74}$ Measures and activities should be taken both in the countries of originand in the target countries, as closely as possible to the problem source. The basic activities to suppress of illegal migrations can be identified as follows:

- external border activities, especially in the countries of origin and in the target countries;

- measures on the external borders, border checks and surveillance,

- activities on the state territory, surveillance of the status of foreign citizens with and without documents,

- International border cooperation.

There are many examples of illegal migrations worldwide. Two groups of illegal migrants can be distinguished: the first group includes the migrants that arrive into their target countries illegally, secretly, through unallowed passages, over mountains, through unmarked border crossings or by water, that is, by boats anchored on unallowed locations in the coastal countries.

The second group covers the illegal migrants who reach their taret countries on a legal basis (for example, with tourist visas, student visas etc.), and than stay beyond the validity of their visas, with the purpose to work ans reside illegally, abusing the confidence gained upon the issuance of the visa with a limited validity period.

As for the method of border crossings - there is a raising tendency of migrants to illegally cross the border organized in large groups, using the migrant smuggling services.

\section{Notional distinction between migrant smuggling and human trafficking}

Pursuant to the information already confirmed by EUROPOL, the number of criminals involved in smuggling of migrants and refugees throughout Europe is at least

\footnotetext{
${ }^{74}$ EC Communication ('COM(2006) 735 final) The Global Approach to Migration one year on: Towards a comprehensive European migration policy'
} 


\section{Securianues}

30 thousand people who are the main perpetuators of crimes related to such acts; they operate in groups, usually consisting of minor criminals from Syria, Turkey, Iraq, Greece and lately from Macedonia and Serbia.

One example given by EUROPOL refers to 15 perpetuators from Syria and Egypt arrested in Greece in 2015. It was confirmed that only that group gained 7.5 million euros from human trafficking. What characterizes the mixed migrations as well as their organizers is the fact that they are used for othe crimes as well such as weapon and drug smuggling.

In order to obtain a better picture of the difference between migrant smuggling and human trafficking, the following two phenomena can be clearly differenciated through an analysis of their existing definitions:

- the primary purpose of human trafficking is exploitation of its victims.

- The noltion of migrant smuggling implies assistance in their illegal intrusion into the target country; but, unlike the victims of human trafficking, the smuggled migrants have previously agreed to be smuggled.

- The people intending to illegally enter another country most frequently are the first to come in contact with their smugglers.

- Human trafficking is most often considered as a crime against the basic human rights, while migrant smuggling is treated as crime against the state, as its immigration regulations are broken.

- Migrant smuggling always implies a transnational element and is primarily directed against the interests of the state and not against an individual, i.-e the smuggled person.

- Human trafficking does not have to include international elements and can be carried out within the borders of one single state.

- In some cases human smuggling can be transformed into human trafficking, i.e the irregular migrant can become a victim of traders.

But, a large number of smuggled people become victims of human rights violation. Many scientists that have researched trhis phenomenon agree that in practice, the differences between smuggling and human trafficking are not always obvious and can grequently overlap.

There is a considerable need to differenciate between these two notions: the first one implies a human trafficking victim, who is often traumatized and needs proper medical aid, while in the second case, there is an illgal migrant, a person who has been 


\section{Seccurity}

transferred across the border in inhumane conditions, but are mostly in a very good physical condition.

For example, a person can seek some help from smugglers in order to reach a particular destination illegally, and fall victim of exploitation at the end of the journey, for example, by working in slavery conditions in order to provide financial compensation to the smuggler.

In other situations, female migrants can be aware that they are going to be prostitutes, but unaware of the violence and exploitation implied. In the last two cases the crime committed is the one of human trafficking.

\section{Asylum}

The asylum right is a constitutional category in Macedonia. Republic of Macedonia guarantees asylum right to foreigners and apatrides, exiled for their democratic political belief and activity; it is a form of protection offered by a state on its territory pursuant to the principle of non-return and the internationally or nationally regognized refugee rights.

Asylum is granted to a person who is unable to seek protection in their country of citizenship and/or residence for fear of prosecution based on race, religion, and nationality, membership in a social group or political movement.

The Law on Asylum and Temporary Protection regulates the conditions and the procedure of obtention and termination of an asylum right of a foreigner or and apatrid seeking asylum in the Republic of Macedonia, as well as the rights and obligations of asylum seekers with a granted asylum right in the Republic of Macedonia.

Novelty: the migrant can, in written or in spoken form, express intention to submit an asylum right applicationin front of a police officer of the Ministry of Interior, who issues them a sample of the certificate on their expressed intention and advises them to submit an asylum requirement within 72 hours.

The asylum right implies protection granted to the following categories of people, by Republic of Macedonia under the conditions and in a procedure envisaged by this law

- A recognized refugee (a refugee according to the Convention on the Status of Refugees of 1951 and the 1967 Protocol on the Status of Refugees) and 


\section{Seccurility}

- A person under subsidiary protection

Almost 60 million of people have been forcefully removed worldwide, due to conflicts, no matter if the relegation happens within their countries or in other countries where they are refugees. This is the highest number ever recorded, as pursuant toth e new Report of the UN High Committee for Refugees and is equivalent to the whole population of Italy.

The number implies 8.3 million people more than in 2013, mainly due to the Syrian war, the advance of Islamis State in Iraq and the renewed conflicts in Africa.

The number of refugees increased from 11.6 to 14.4 million people (not counting the 5.1 million of Palestinians) on the world level for the same period, which has been the largest annual increase since 1990.

Syria is the country of origin of most refugees, who outnumber those from Afghanistan, which had been holding the leading position for more then 30 years.

Six out of the ten countries of refugee origin are African. The current conflicts in Somalia, South Sudan, Congo and Central African Republic make them leaders in the negative statistics.

\section{Key principles of the migration policy of the Republic of Macedonia}

Upon the designing of the migration policy for the period of 2015-2016, Republic of Macedonia remains devoted to respect of the basic principles and recommendations of the international organizations especially of the International Migraiton Organizaiton ${ }^{75}$, which regard the migration management and have universal meaning.

They are the following:

Respect of international standards, human rights and protection. This refers to respect, protection and granting of migrants' human rights as pursuant to international law, protection of vulnerable categories of migrants, as well as of international standards related to migrant workers. This principle also implies supressionof xenophobia, racism and discrimination, as well as incorporation of gender equality into migration policy.

${ }^{75}$ International Organization for Migration,"Framework for Migration Governance". 


\section{Securiagues}

A comprehensive and proof-based policy, developed in close cooperation with relevant partners.

Implementation of a thorough and coherent migration policy on a national level, designed on the basis of relevant insights, with the participation of all government institutions in close cooperation of all parties concerned, and the engagement of relevant parties on a national, regional and international level (government agencies, $\mathrm{NGO}$ 's, associations, migrants' organizations etc.).

Addressing the socio-economic needs.

Integration of new migrants, re-integration of returnees and providing acess to healthcare and social services for all migrants.

Support to labor migration (including the temporary and circulatory migration) and support to brain-gain (",brain inflow"). Integration of migrations into the development processes through decreasing of costs on foreign currency remittances, their productive use and the so-called brain-gain (",brain inflow").

A policy that is adaptable, i.-e capable to meet the challenges in times of crisis, and alleviate the risks related to migrant movements.

Allowing access to legal migration. This is achieved through transparent and efficient application of migration-related legislation.

Provision of regular migration channels as pursuant to the national development policy. Collection of credible and timely information on migration flows and dissemination of appropriate information on migration policies and procedures to enable the migrants to bring decisions based on relevant information. Efficient implementation of the visa regime and efficient management of migrations and development.

The policies, the action and operational plans in the mentioned fields should refer to several specific fields and their particular aspects, designed so as to make it possible that their specific purposes correspond and be consistent with the general aim of the migration policy in a wider sense as well as the other relevant policies.

Therefore, the basic principles that are applied and determine the design of the Macedonian migration policy are as follows:

- Consistency - coordination of specific policies (policy related to the citizens of the Republic of Macedonia abroad); policy of immigration and integration of foreigners; policy towards illegal migration, migrant smuggling and human 
trafficking; policy of asylum and protection of refugees) as well as coordination with migration policy in a wider sense of the word;

- Compatibility - coordination of the migration policy with the economic, social, demographic and culturological policy of the Republic of Macedonia. Verification of the coordination of the purposes of the said policies, the efficiency of the enacted measures, the influence of migration policy and continuous adjustment to the changes in the migration processes;

- Transparency - visibility/clarity in the enactment of certain policies and the overall migration policy in relation to the administrative procedures and spending of funds so as to provide for public confidence and support;

- Sustainability - continuity of designing, preparation and monitoring of the implementation of the measures and activities of migration policy, imdependently from the changes in the organization structures.

Besides the principles mentioned above, in order to successfully implement the migration policy of the Republic of Macedonia it is necessary to fulfill the following basic conditions - Responsibility of the ministries in charge and of other institutions for the progress in the fulfillment of the policy aims and their implementation;

- Public educational and information campaign in view of the development of a large-scale support to migration policy;

- Advancement of the national capacity to analyze, create and implement of the migration policy, and

- Partnership with the countries of origin and destination, as well as with the regional and international organizations, the NGO's and the other organizations of civil society of the private sector and the other relevant factors. ${ }^{76}$

\section{Conclusion}

It is obvious that the strengthening of the institutional capacities, the improvement of the cooperation among competent subjects on the national, regional

\footnotetext{
${ }^{76}$ Resolution of the Republic of Macedonia on Migration Policy 2015 - 2020 (Official gazette no. 8 of 16.01.2015)
} 
and international level are the basic preconditions for efficient and safe management of the migration processes, especially when they appear in the form of cross-border migrations.

Realizing the Balka events so far, and the risk and threat estimation, it can be emphasized that the Regional security is a problem, as the Region lacks the continuity of its monitoring and appropriate and timely solutions thereto.

The building of regional capacities on the Balkans, in view of fast exchange of security-related data among the countries, impses the need to a common intelligence center with counter-terrorist activities on the Balkans that will control all the activities of the militant individuals who will participate in the global djihad in Syria, Iraq and other countries, who than return toth e Balkans or to EU by the Balkan route, can considerably contribute to efficient migration maganement.

The concept of integrated border management in EU - is the basis to a future development of IGU in Maedonia, and, in that direction, it is necessary tyo apply this common model of border management, in view of the protection of internal security, prevention and identification of illegal migrations and cro-border crime.

The change in the structure of the illegal migrants meant the incurrence of certain challenges which were not popular in the recent years (lack of translators from/into Arabic language and the dialects spoken by the illegal migrants, lack of valid contracts on readmission with the Asian and African countries, increased number of people and their prolonged period of residence in the Shelter Center for Foreigners, considerably higher finances for their possible return to the countries of origin, lack of programs on assisted intended return, public health risks etc.)

The increase in the number of asylum seekers outside the region created a situation in which the West Balkan countries do not actually have access to translators from/into all the languages spoken by these people, especially from/into Pashtu, Dari, Urdu, Farsi and other languages. The availability of translators of the languages spoken by the asylum seekers is also important for language analysis. It is performed in case of doubts related to the identification of the asylym seeker's country of origin.

Besides the identification of the person's identity, appropriate identification implies the recognition of the category to which the person belongs: asylum seeker, victim of human trafficking, unaccompanied minor, illegal migrant, crime perpetuator etc. 


\section{References:}

1. Constitution of the Republic of Macedonia (" Official Gazette of the Republic of Macedonia, no. 8/92, 42/01).

2. Гоцевски Т., Основи на системот за национална одбрана, Филозофски факултет, Скопје, 2006 година.

3. EC Communication ('COM(2006) 735 final) The Global Approach to Migration one year on: Towards a comprehensive European migration policy'.

4. Шенген акциски план, Влада на Република Македонија, октомври 2009 година. Релевантни прописи за нерегуларната миграција од Schengen acquis.

5. Регулатива (Е3) 6р.562/2006 на Европскиот Парламент и на Советот, од 15.03.2006 година, за основање на Кодексот на Заедницата за правилатаза движење на лицата преку границите (Шенгенски граничен кодекс), (Службен весник на Европската унија, OJL 105 од 13.04 .2006 страни 1-32).

6. Насоки за интегрирано гранично управување во Западниот Балкан, Европска Комисија (EC) октомври 2004, ажурурана верзија, проект "Поддршка и координација на стратегиите за (IBM), јануари-2007 година.

7. Миленкоски М, Државните граници на Република Македонија и асоцирањето во Европската Унија, Скопје, 2005.

8. Mesic M, Harmonizacija evropske migraciske politike: neuspeh politika imigraciske kontrole sedamdesetih i osamdesetih godina 20. stoljeca, Filozofski fakultet, Zagreb 2003 godina.

9. Николоски, 3. Миграции - контраиндикации или причина за позитивни ефекти, Скопје 2010 година.

10. Резолуција за миграциската политика на Република Македонија 2009-2014 г. (Службен весник на РМ бр.6 од 15.01.2009 година)

11. Резолуција за миграциската политика на Република Македонија 2015 - 2020 (Службен весник на РМ бр.8 од 16 јануари 2015 година)

12. Бакрески 0., Координација на безбедносната заедница на Република Македонија, Маринг, Скопје, 2005, година.

13. Хју П. Поим за глобална безбедност, Табернакул 2009 година.

14. http://faktor.mk/2015/06/20/grafika-zemjite-od-kade-doagaat-najmnogumigranti/ 


\section{Seccurity}

15. www.iom.net/jahia/jahia/pid/359

16. http/www.setimes.com 